торое применяется въ больницахь, гд⿱⺊口 эпилептики обычно ве получають никакого улучшенія.

\title{
A. Ццареградскій.
}

Die Gesichfspunkte und die Tatsachen der psychophysischen Methodik. Von G. E. Müller Wiesbaden. 1904. p. 244.

Выпуская въ свйть свой трудъ, авторь задался пйлью собрать и обтединить, васколько әто представляется возможнымъ, всъ теоріи и основы пгсиофияической методики, какія существовали и нарождаптся со времени Fechner'a. Не мало внимапія обращено авторомъ на приведеніе вт болье или мен质е стройную систему литературныхъ источников'ь. ШІомимо гритическаго обзора психофизической методики автору удалось заполнить тй пробћлы, которне существують въ ббпир ном' эмпирическомъ матеріал孚 интересующей его области. Введеніе вт свой трудъ G. Müller посвящаеть общему обзору методики и выясненію задачь ея примьвненія. Особенно тщательно разработаны отдыльныя главы, трактующія о постоянныхъ раздраженіяхь при изсльдованіи „пороговъ“, объ опредъъ.леніи эгвивалентныхь раздраженій, о разниц в раздраженій и др. Принимая во вниманіе, что систематическое ознакомленіе съ методами психофизическихь изсльвованій значительно облегчаеть трудъ изученія методики, что изложеніе предмета отличается посльвдовательностью и ясностью, нельзя ве признать за работой автора солиднаго вклада вь область психофизики, шагъ за шагомъ завоевывающей себб видное мъсто въ ряду экспериментальныхь наукь.

\section{л. Айхенвалъдг.}

Этіологія идіотизма сравнительно съ таковой при д委тскомъ перебральномъ параличъ. - Dr. W. Koenig. (Allg. zeitschr. für psych. 1904. B. 61).

Авторь на основаніи собранваго и статистически разработаннаго матеріала приходить къ заключенію въ существованіи трехъ несомньнныхъ этіологических э моментовъ для возникновенія мозговыхъ де́тскихь параличей и идіотизма. Таковыми авторъ считаеть 1) тяжелые роды (асфиксія), 2) травму черепа и 3) ипфекціонныя забольванія. Всъ остальные моменты могуть считаться предрасполагающими, а именно: 
насльдственное отягощеніе (potus), кахексіи, особенно туберкулезъ и lues. Въ общемъ авторомь изсльдовано 70 случаев' параличей и 260 идіотизма, при чемь имь получены сльдующіе сравнительные результаты: душевныя забольванія роди-

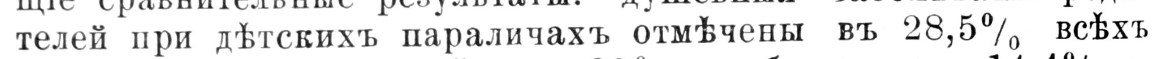
случаевъ, при идіотизмь-въ $32 \%$; туберкулезъ-14,4\% и $13,8 \%$; potus родителей: $23 \%$ и $15 \%$; тяжелые роды $11,4 \%$ и $10 \%$; lues $7 \%$ и $10 \%$. Во многихт случаяхь обоихь страданій безь опредъленной „этіологіи“ необходимо предположить совокупное дййствіе ньсколькихь моментовь или, по выраженію Freud'a, „конкуррированіе“ ихь.

Наконець авторь уббъжденъ въ томь, что нерьдко идіотизмь вызывается наличностью эпилепсіи, симптомы которой подчась наблюдаются и при дытских' параличахъ.

Л. Айхенвальдб. 